\title{
Living across the Borders: The Mobility Narratives of Romanian Immigrants in Spain
}

\section{Silvia Marcu*}

\begin{abstract}
This article seeks to analyze the mobility of Romanians within Spain, taking into account the current economic crisis that is affecting labour markets in Spain and Romania, and its impact upon people. Using the perceptions of Romanians, the paper examines their experiences and their understanding of their process of mobility and return as Europeans who have a right to free circulation but limited working rights in the enlarged European Union (EU). To carry out this research, the author used the qualitative method of in-depth interviews with 80 Romanian immigrants engaged in labour mobility between the two countries. The article highlights the role played by borders in studies of mobility and suggests that migrants may have varying perceptions concerning place and mobility. By looking at immigrants' narratives the article seeks to produce a framework that reflects the transformation of immigrants into mobile citizens within the context of the EU.
\end{abstract}

Keywords: immigrants, mobility, Romania, Spain, European Union, labour

\section{Introduction}

The European Union (EU) was built upon the premise of free movement of persons across its internal borders. Following the events that changed the world map and the map of migration in Europe at the end of the $20^{\text {th }}$ century we are witnessing borders opening up towards the east, a dynamic that was brought about with the two enlargements of Europe in 2004 and 2007. This meant an increase in human mobility within Community territory by incorporating a large influx of people from Eastern Europe into the developed countries of the EU (Meinhof 2002; Favell 2008).

1) First, this article analyzes the process of mobility practices on the part of Romanian immigrants within the enlarged EU. It explores human mobility as a social process that is necessarily complex, while focusing on the perceptions of immigrants as central actors in a migration project that, due to their mobility, situates them between their country of origin and the country of their destination (Marshall \& Foster 2002). Therefore, the article asks, "What is Romanians' experience of mobility?"

\footnotetext{
*Silvia Marcu is Postdoctoral Researcher "Ramón y Cajal" in the Spanish National Research Council. For the last decade she has been conducting research into international migration, identity and mobility; borders and flows of immigration from Eastern Europe to Spain; studies of Geopolitics: Eastern Europe, Russia, European Union (EU) and International Relations. E-mail: silvia.marcu@cchs.csic.es

Acknowledgements: This work was supported by "Ramón y Cajal" Contract [RYC-2009-03834] as financed by the Spanish Ministry of Science and Innovation. This article also comes as a result of the research project entitled: "Eastern European Migration to Spain in the context of border geopolitics: circulatory mobility and return," [CSO 2010-14870], with funding from the Spanish Ministry of Science and Innovation and coordinated by the author.
} 
2) Secondly, taking into account the precarious situation of Romanians seeking work in Spain, the article examines the manner in which Romanians understand their process of mobility, sense of place, and the perceptions of members of their community immersed in that process.

3) Thirdly, in the field on theory, the article asserts the contribution that border studies can make understand human mobility in view of the EU open-borders policy.

This broader sense of borders might help to bare the soul of human mobility, namely, the condition of being continuously between here and there. Thus, borders and mobility are not necessarily opposed to each other, but can also be linked in a constructive way.

Research was conducted within the context of the economic crisis that affects both Romania and Spain and which impedes Romanians' success in finding employment in the labour markets of either country. The mobility of Romanians towards Spain increased as of 2002 and peaked in 2007 following Romania's entry into the EU. Throughout this period, despite restrictions in the European market, Romanians found work in Spain more easily than in Romania, especially in construction and the service sector.

Between 2007 and 2009, Spain imposed a moratorium that prevented Romanians (and Bulgarians) from freely entering the labour market ${ }^{1}$. After 2009, Spain lifted the moratorium and allowed free circulation for Romanians and Bulgarians ${ }^{2}$. In 2011, due to the severe economic crisis in Spain and the incessant flow of Romanians $(861,584$ registered, 30.0 per cent of whom are unemployed and 15.7 per cent inactive), (Figure 1) the European Commission ${ }^{3}$ approved a temporary measure (Order PRE2072/2011) that restricted the right to employment for Romanians who emigrated to Spain as of that date. ${ }^{4}$

The results of the article must be considered in the context of an economic crisis that currently affects both countries involved. Despite restrictions on free access to labour markets and the lack of the right to work, Romania's entry into the European community has converted Romanians into European citizens who enjoy the right of free circulation that allows them to be 'mobile' (Marcu 2010). Hence, the term 'mobility' is used instead of 'migration'.

\footnotetext{
${ }^{1}$ Austria, Belgium, France. Germany, Ireland, Italy, Luxembourg, Malta, Netherlands and the United Kingdom will continue the period of restrictions until 2013.

${ }^{2}$ Since that date, both Romanians and Bulgarians have been able to circulate freely within Spanish territory in order to work. Until that date, immigrants from the two countries had but limited circulation of up to three months to work without a residency permit in Spain. The ending of the moratorium, however, did not go into effect for all of the countries in the Schengen Area of the EU. In order to work, Romanians and Bulgarians are required to obtain a work permit according to a moratorium which lasts until 2014.

${ }^{3}$ European Commission (2011). Decision to Authorise Spain to Temporarily Suspend the Right of Free Circulation for Romanian workers (Regulation 492/2011) Brussels. 11.8.2011 C (2011) 5896 final.

${ }^{4}$ While this does not affect self-employed workers nor those receiving unemployment compensation, Spain's decision to demand work permits for Romanians only affects those who are registered with Social Security. The effects of the re-activation of the transit period will be re-evaluated at the end of 2012, when Spanish government agencies decide whether or not to continue with it. The European Commission authorized these temporary limitations in view of Spain's economic climate, which has had serious consequences in the labour market: 1) the highest rate of unemployment in the EU (21per cent as compared to the 9.4 per cent average for the EU and 9.9 per cent for the Eurozone, b) slow economic recovery, with only 0.3 per cent growth in GNP during the first 3 months of 2011 as compared to the previous 3 months, and to 0.8 per cent in the EU and the Eurozone. (Spanish Ministry of Labour and Immigration, 2011).
} 
The first part of the article examines mobility on the part of Romanians in Europe and Spain, followed by a brief section on the status of mobility within the context of the enlargement of Europe. It continues with an analysis of experiences of borders, work, and the return of the interviewees and their perception of free circulation in Europe within the context of the process of mobility. Finally, the conclusions offer a framework for the formation of a mobile citizenry in an expanded EU.

\section{Patterns of Romanian Mobility in Europe and Spain}

The fall of the Iron Curtain (1989) meant the first exercise of freedom along with the fall of the totalitarian system for the people of Eastern Europe. Before 1989, most migration was clandestine, heading for developed Western European or American economies, which used to accept asylum requests (Serban \& Voicu 2010). This added to the repatriation migration of German, Jewish and Hungarian ethnics (Michalon 2009). From 1950 to1983, 232,326 German ethnics demanded political asylum in Germany (Diminescu 2009: 46) .

After 1990, Romania's transition brought about a sharp decline in the levels of satisfaction with the living standards caused by higher unemployment rates, precarity and increased poverty. Working abroad seemed to be one of the few strategies for coping with economic and societal changes (Sandu 2006).

Romanian emigration towards Spain took place in three stages. The period 1990-1995 was a trial-and-error exercise in terms of work migration. During this period, 325,900 petitioned for political asylum in Western Europe (Diminescu 2003). Germany received the greatest number of Romanian emigrants (96.88 per cent), followed by Hungary, France, and Austria. According to data from a 2006 survey $^{6}$, from 1990 to 1995, Spain attracted a very low number of Romanians departing for work abroad (about 2 per cent) (Elrick \& Ciobanu 2009).

Especially from 1996 onwards, Romanians' international routes for work have converged towards the southern region of Western Europe, with Italy and Spain as the main destinations. Labour demand, language learning ability, the degree of tolerance, and the existence of Romanian networks already established were influences in the increase of emigrant streams toward Spain and Italy. Romanians have become a prominent immigrant group in Spain over the last ten years (Figure 2).

The period 2002-2007 was marked by the opening of borders under the Schengen agreement, allowing Romanians free circulation within Community territory. Without being previously connected in any special way with Romania, Spain became for Romanians one of the two most popular destinations for working abroad. An agreement was signed by Romania and Spain in 2002 on the regulating and organising the flow

\footnotetext{
${ }^{5}$ In 1978, a bilateral agreement was signed between Romania and the Federal Republic of Germany, assuring that 12,000 ethnic Germans could leave the country every year, and rewarding Romania with 10, 000 German marks for each person.

${ }^{6}$ Source: Spanish National Institute for Statistics, Population Register, national results, 1996-2009, http://www.ine. es/jaxi/menu.do?type = pcaxis\&path =\%2Ft20/e245\&file $=$ inebase $\& \mathrm{~L}=1$, accessed on 2 March 2011.
} 
of labour between the two countries. ${ }^{7}$ The regularization processes implemented by the Spanish government in 2000-2001 and 2005 ${ }^{8}$, eliminating visa requirements at the beginning of 2002, and Romania's accession to the EU (2007) were important events. At the same time, as pointed out by Viruela (2011:43) the economic growth in Spain, supported by the dynamic construction and tourism industries, generated a strong and sudden demand for foreign workers over the past decade. As a consequence, the process of temporary labour circulation that was to reach unprecedented levels began. Also, the development of immigrant networks, paired with the creation of an important number of associations, Orthodox Christian and Adventist congregations, or other Romanian cultural centers, developed immigrants' ties to their country of origin, while also exposing Romania to the cultural values of Spain.

Finally, the third stage began in 2007 and continues at present, having been marked by Romania's entry into the EU. The increase in the flow of emigrants was spectacular in only one year: in 2007, it grew from 211,325 to 603,889 .

Romanian immigrants, who have become citizens of Europe, are in fact regional "free movers", not immigrants (Favell 2008). In 2011, Romanians represented the largest grouping of foreigners living in Spain ${ }^{9}$. It is the Romanian collective that grew the fastest: in 2010, in the midst of a recession, it reached 33,043 while the total number of foreigners dropped by $17,000^{10}$. In 2011 , the Romanian collective in Spain grew to 861,584 registered individuals ${ }^{11}$.

However, since the start of the recession Spain experienced enormous increases in unemployment, with those segments of the labour force that were already at a disadvantage as immigrants. Against the background of the current economic context, what we can call the mobility return of immigrants, now unemployed in Spain, has begun. This return may be a complete geo-psychological process of re-settlement, and it may be an opportunity to evaluate the transformations that people undergo from a distance.

\section{Framework of mobility in the context analyzed}

Mobility is an integral aspect of social life and has become an evocative keyword for the twenty-first century (Hannam et al. 2006). The new patterns of mobility from the East towards the countries of the West are inserted in terms of free circular and temporary movement, incorporation into the undocumented labour market (Favell 2008), transnationalism (Portes 2001; Vertovec 2009; 2011; Glick Schiller et al. 1995), and the creation of transnational networks that include mobile return.

In transmigration studies, as a major analytic tool, borders are usually considered boundaries, the physical lines on the ground, and therefore are seen as beginnings and endings of migrant transnationalism (Gielis 2009; Newman 2006; Van Houtum 2005). The barrier function of borders needs to be low for migrant transnationalism to take

\footnotetext{
${ }^{7}$ Law 464 of July 2002. The Agreement regulates the flow of labour, establishes mechanisms for communicating employment offers, guarantees workers' rights, regulates temporary work, and facilitates voluntary return.

${ }^{8}$ Some 604,357 immigrants in Spain were legalized in 2005. Ministry of Interior 2007.

${ }^{9}$ http://www.mtin.es/en/index.htm accessed on 5 September 2011.

${ }_{10}$ Spanish National Statistical Institute http://INE.es accessed on 10 October 2011.

11 http://www.mtin.es/en/index.htm accessed on 5 September 2011
} 
place. Vertovec (2004: 979) states that the transnational activities of migrants challenge the borders of states. He developed the term "bifocality" to grasp the dual orientation of migrants. Bifocality is the acute awareness of living in-between, which comes to the fore in all kinds of everyday situations. Faist (2000) strives to conceptualize domain of crossborder social relations he refers to as "transnational social spaces." In this context, circular migration is a form of migration that is managed in a way to allow some degree of legal mobility between two countries. Employed by migrants, it is a local strategy that links social and symbolic capital and which leads to the use of short-term space-time strategies (Sandu 2006; Sandu 2009). Following Recchi and Favell (2009), many Romanians work in Spain or Italy for several months in order to be able to stay at home. Immigrants bring their cultural capital to foreign countries, while their social and symbolic capital remains in their place of origin. Transnational mobility is developed in the framework of strong relationships between the countries of origin and destination, based on the premise that migrants have the freedom to decide. In order to mobilize local resources, both the social ties and border symbols established by migrant pioneers are needed (Faist 2007). The migration chain takes place if mutual mechanisms, family solidarity and social relationships work and if there are networks created within the country of destination (Goldring 1996). The emergence of this self-perpetuating dynamic might then give rise to a voluntary migratory chain which embraces the phenomenon of return as a form of mobility. Return migration is a sub-process of international migration, which reactivates patterns of human mobility (Cassarino 2004). Therefore, rather than dissolving the concept of return, the transnational paradigm is actually broadening it by treating it as a process, sometimes reversible, sometimes partial (as among those who choose to live bilocally and/or transnationally (for example, dividing their time between two homes in two different states). As regards the definition of terms, in this paper we follow Long and Oxfeld (2004: 4) in making the distinction between return migration - a physical relocation of the migrant with the intention of staying for some time, maybe permanently, in the place of origin - and return, a broader concept which includes return migration and repatriation but which can also be imagined or provisional, encompassing various shortterm visits such as holidays. All are return mobilities (King \& Christou 2011).

Transnationalism also offers scholars fresh insights into the ways in which migrants maintain ties to their places of origin while simultaneously adapting to their new environments. In fact, the concepts of place and mobility are intricately related. Several scholars have argued that individual experiences are becoming dissociated from place because of increasing mobility (Albrow 1996; Calhoun 1991). However, other scholars have argued that people who move do not necessarily belong to the places where they are staying (Hannerz 1996). This literature tends to depict a globalized world where everybody is on the move, mobility appears as a basic human condition and place attachment becomes increasingly precarious.

According to Massey (1995), place is a social construction since we live in an unstable world where, as a consequence, more and more people link the notion of place to stability and security. However, precisely because of this, we should not view places as spaces isolated by their security but as interconnected points within a larger system.

Morokvasik (1999) noted that immigrants from Eastern Europe show an inclination towards mobility as well as towards the capacity to create extensive networks throughout 
Europe. An area of such characteristics is built upon precarious and ever-changing solidarities, and its actors are men and women who are prepared to emigrate at any moment and overcome distances and barriers.

\section{Methodology}

In order to carry out the study, I used a qualitative methodology that helps understand the complexities of human behavior (Ezzy 2002: 29). In addition, a form of participantobservation was used to help place the stories of the interviews in their wider context. I also used quantitative data from the Spanish Ministry of Labour and Migration as well as the National Statistical Institute.

This research is based on 80 in-depth interviews ${ }^{12}$ with Romanian immigrants who practice mobility between the European and Spanish labour markets. I interviewed working age (18-55 years of age) males and females who had either secondary or university-level education, who had lived at least 4 years in Spain and whose movement had intensified over the last few years following Romania's admission to the EU. Persons who had worked in Spain and had partly returned to Romania, as well as persons affected by the new restrictions on the labour market were also interviewed. The decision to interview trained immigrants was based on their knowledge of the process of mobility and the greater difficulty in finding employment in their own country as well as in Spain, a fact that supports their mobility. The interviews were conducted in Spain in the regions that received the greatest numbers of Romanian immigrants (Madrid, 25; Zaragoza, 5; and Castellón de la Plana, 10) and in Romania [Baneasa and Henri Coanda Airports in Bucharest, 10; the provinces of Teleorman, 20 and Vaslui (Birlad), 10 from which large numbers of Romanian emigrants emerge]. ${ }^{13}$

Given the great amount of data obtained, we have opted to use the thematic analysis, which is a good example of the technique of reducing data for qualitative research $\left(\right.$ Grbich 2007) ${ }^{14}$. The advantage of thematic analysis is in its flexibility, both in terms of the variety of data sets it can be applied to as well as its compatibility with different research paradigms.

In order to answer the research questions, the study began under the theoretical supposition that migrants are active in their decisions and experiences of mobility. This supposition points to relevant aspects in the field of theory and includes the arguments of phenomenologists concerning the nature of experience, analysis of human activity through symbolic and hermeneutic inter-action, and the new criticism of social science research which affirms that in a global and mobile world, societies should not be seen as limited, and therefore require new means of social analysis.

Interviews were transcribed, coded and analyzed according to the issues that emerged. The following issues were identified: experience of borders, mobility, under-employment, return, the place-mobility relationship, and perceptions regarding European citizenship.

\footnotetext{
12 The author conducted all of the interviews in Romanian and later transcribed them

${ }^{13}$ The interviews were conducted in Spain in October/November 2010, January through March and July/August 2011, as well as December 2010 and April/May 2011 in Romania.

${ }^{14}$ The goal of thematic analysis is to locate the most common and salient themes amid the data. These themes are capable of representing the data group in the form of a thematic map of a phenomenon or process.
} 
Living across the Borders: The Mobility Narratives of Romanian Immigrants in Spain

\section{Experiencing Mobility}

The current experience of mobility on the part of Romanians has deep roots in their country's Communist past. As has been noted by Romanian researchers (Diminescu \& Lazaroiu 2002), an analysis of the current phenomenon of mobility requires references to mobility existing in Romania before 1989. Three forms of mobility can be identified: 1) Internal mobility, specifically during the Communist period, by which Romania's rural population engaged in daily labour mobility from their homes to the nearest urban centers. After the fall of the dictatorship, as of the beginning of the 1990s this phenomenon diminished as inflation grew, manufacturing slumped, and urban unemployment increased. This was reversed as of 1997, when migration from the cities to smaller towns increased (Rotariu \& Mezei 1999); 2) short-term mobility towards neighboring countries (Yugoslavia, Hungary, and Turkey) which became known as "suitcase business", (Wallace \& Stola 2001), which increased following the end of the Ceausescu regime and during the final years of the dictatorship as persons took risky short trips to neighboring countries in order to purchase basic necessities; 3) lastly, international mobility, which started in 2002 when, following the lifting of visa restrictions for EU countries, mobility strategies emerged in which they spent 3 months in a host country and alternated with 3 months in Romania. Spain was one of the most popular destinations. Mobility increased after 2007 when Romania became a member of the EU. It is thus that it is possible to speak of a consolidation of the practice of mobility on the part of Romanians (Diminescu 2003).

According to the characteristics and number of interviews undertaken, Romanians' labour mobility in Spain shows the following dynamic: 40 of the 80 interviewees (50 per cent) arrived in Spain after 2007 and travel at least 3 times a year between Spain and Romania. 32 of the interviewees (40 per cent) arrived in Spain after 2002 and returned to their home country at least once and emigrated again, while 8 (10 per cent) interviewees arrived in Spain before 2002 when visas were required and returned to Romania one or two times each year.

Borders are a fundamental aspect of mobility and, while the majority of interviewees note that they do not need visas for entry into the country, they are required to have at least $100 €$ per day while in Spain. After having lived three months legally in Spain without finding work, they are then considered illegal. A significant fact is that all of the interviewees who arrived in Spain after 2002 obtained work permits and residency following the extraordinary regularization of 2005. Of the 32 interviewees in this situation, 25 lost their permission to work because they could not renew their documents and are now faced with having to work illegally.

The border was important because I came and went many times, by various routes; I know the checkpoints and I also travel by bus. They demanded that we have enough money to live as tourists in Spain. If you did not have the money, you just pay the bus driver $20 €$ and take your chances. The bad thing is that upon arriving, if you find nothing, you have to make do. I even slept in a park. In 2005, Spain gave us documents but, when I could not renew them, I lost the right to work and so I had to get work through my cousins (male, age 34, Madrid). 
Among those who emigrated before or after 2002, as well as those who returned at least once and then emigrated again following Romania's admission to the EU, there was notable flexibility at the border upon their new exit and valuable networks of family and friends had been created. However, almost half of the interviewees arrived in Spain after 2007. For them, the experience of mobility is very intense and part of a flexible border context.

In Spain, they declared themselves and were registered as citizens of Europe, obtaining EU citizenship that until August 2011 gave them both the right of residency and the right to employment in Spain. Ten of those persons interviewed emigrated during the last 3 years, following Romania's admission to the $\mathrm{EU}$, and have had intense experiences of cross-border mobility. Interviewees noted that it is lack of employment that is the most important cause of mobility, and that mobility helps in finding work in a labour market that is in crisis not only in Romania (where salaries low ${ }^{15}$ but prices of goods are the same as those in the rest of Europe), but also in Spain- which is experiencing some of the highest levels of unemployment in many years.

In the 90s, people emigrated because they were unemployed or because they wanted to earn more. Now, once again, with the aggravating factor that finding a better job is a challenge anywhere in the world. The good thing now is that one needs not emigrate, but move and can do so (male, age 32, Zaragoza).

\section{Mobility and underemployment}

Analyzing Romanians' experiences of labour mobility, means getting to know their situation in the Spanish labour market, following Romania's EU entry, a period that coincided with the beginning of the economic crisis. The number of workers affiliated with Spanish Social Security dropped from 429,427 in 2007 to 287,225, while the rate of unemployment increased over the same period from 60,826 to $191,400^{16}$ (Figure 3 ). According to data from the Spanish National Statistical Institute, $55.4 \%$ of the total number of affiliated persons were noted in the general category (construction, industry, commerce and transport), while $28 \%$ worked in the agricultural sector, $8.9 \%$ were self-employed and only $7.7 \%$ were domestic workers. However, despite the increase in unemployment and drop in affiliation with Social Security, there was a concomitant increase in the flow of Romanian immigrants. Therefore, the crisis expanded the process of mobility. It is a precarious mobility because, excluding retired persons and children, some 300,000 Romanians - more than half of those registered in Spain work in the underground or informal economy - have not yet found work or have been made redundant and, because they have not worked in the formal economy, may not receive unemployment compensation. They are affected by the restrictions imposed by Spain's government upon

\footnotetext{
15 The average salary in Romania was 1,600 lei in May 2012 http://www.ziare.com/social/salariu/romanul-cucastiguri-medii-de-ce-in-categoria-saracilor-opinii-1168318

Information accessed on 23 May 2012.

${ }^{16}$ Spanish Ministry of Labour and Immigration http://mtin.es, accessed on 14 October 2011.
} 
the labour market ${ }^{17}$. Some $75 \%$ of those interviewed are in this situation, having lost their jobs in Spain and their right to unemployment assistance.

I have worked and continue to work in homes. I merely changed houses, but not work. I never was registered for Social Security, and will have to sign up as self-employed; no one hires me because I work by the hour, 40 hours a week (female, age 44, Madrid).

None of the persons interviewed at Castellón de la Plana (10), who are engaged in mobility between Spain and Romania to find work, were employed.

In 2007, I decided to work in Spain because I had been made redundant. I worked in construction, undocumented, with my cousin until 2008 and then returned to Romania because the work ended in Spain. My wife works by turns with her sister in caring for elderly people in Spain for six months, followed by six months in Romania. I tried selfemployment in Romania, but it was not successful. In 2009, I returned to Madrid, but when I found nothing, I went to Almería to work in the fruit harvest. When the season ended, I returned to Romania and re-joined my wife. In 2011, I came to Castellón and harvested oranges but, since now I have no work, I will return to Romania (male, age 46, Castellón).

The intense pace of mobility - "I was without work in two countries", "I come and go", "Over the last two years I have worked for 5 months at a time without a contract", "I work in Romania and here, without documents", "I don't have work; I look for it, but with the moratorium no one will give me papers", - increased dramatically, as well as the precarious underemployment found in both countries.

\section{Return as mobility}

As of 2009 and because of the economic crisis, Spain's government designed plans for the voluntary return of unemployed immigrants. It was in this context that the respective Ministries of Labour of Romania and Spain signed an agreement on facilitating the voluntary return of Romanian workers in Spain, especially the unemployed or those about to become redundant ${ }^{18}$. However, as of the end of 2010, only 187 presented themselves in compliance with the agreement ${ }^{19}$. Those interviewed expressed their divergence with the agreement, and pointed out that the Romanian government had not acted as it had promised.

\footnotetext{
17 Also, according to the Directive, Romanians residing in Spain as of 22 July 2010 but who were not employed (activated by Social Security) or who could not prove that they were seeking employment (registered job-seekers) are affected by Spain's new moratorium and are required to have a work permit.

${ }^{18}$ The Agreement proposes that Romanians should receive information about the labour markets in each of the two countries in order to facilitate their mobility. The plan for return includes a payment of a sum of money for travel or for those who were made redundant; the entire amount of the unemployment compensation was to be paid in one lump sum for the returnees' agreeing not to return to Spain for two years.

${ }^{19}$ General Directorate for Integration of Immigrants, State Secretariat for Immigration and Emigration, 2011.
} 
It is a loss, because Spain took action but Romania does nothing so that people can return. I have seen that people have lost confidence in their own country and are afraid to return (female, age 39, Madrid).

Because of Europe's policy regarding the free circulation of persons, Romanians did not easily choose to return, but instead prefer return as part of a dynamic and continuous movement. As pointed by Sandu (2010) in order for return to occur, immigrants need a personal or family plan, accumulated resources and plans to work or invest in their country.

This complexity has been recognized specifically in the context of return migration by King (1978), who points to the complexity of people's moves, their reasons for moving and the level of development in places of origin and destination. Return becomes diluted in movement and is difficult to control since decision-making is instantaneous and rapid, while the length of stays in each country are variable. At the same time, return within mobility is facilitated by the relatively low cost of travel. The experiences of returning to the country of origin as a part of mobility exhibit the level of turbulence in which Romanians live while moving.

In the interviews, we detected three categories of return as part of the process of mobility:

1) Persons who, because of working in the informal labour market and lacking a contract, return to their home country every six months. They then stay in their home country for six months, where they seek labour strategies while also building or repairing their homes.

I work in Spain during the orange and olive harvest. I save money and return to Romania for six months to build my house. I hope to finish it within two years; I build it in stages, as I can (male, age 45, Castellón).

2) Persons - especially women - who work in the informal labour sector in caring for elderly people, returning three times each year and remaining for three or four months in their home country. During those periods, they are replaced by other Romanians. It is work that is done in rotation, which permits two or three women from the same network to work part of the time and care for their families and children in their home country at the same time.

I will remain in Romania until after Christmas and then I will go back. My sister is in Spain now. We work by turns in the same home, caring for an elderly lady. It is good that her sons understand and allow us to take turns. So, we can provide care for a while and also take care of our children, whom we leave here (female, age 46, Birlad).

3) Persons who, not having found work, have a disorderly return and are always at the whim of the labour markets in either of the two countries. This category also includes those persons who became redundant in Spain, live in their country but return in order to collect unemployment compensation. 
Last year, I went four times to collect unemployment compensation of $450 €$ per month. With that, we can live here in our town. In any event, even though we may find employment here in Romania, we cannot earn that much. Thus, I continue looking for work in Spain, but I prefer temporary work if I can find it and, of course, I would not work 10 hour shifts continuously as I did before (male, age 43, Tiganesti).

The experiences that participants have had of mobility in the past may have a significant impact on their plans for the future. Leaving, remaining and returning are new aspects of life for people who, until recently, could not travel freely. The EU and the Schengen Area have thus provided a culture of mobility for Romanians.

\section{Understanding Mobility: "Inside, but outside the EU"}

The interviewees are conscious of the complexities of mobility. They acknowledge the importance of their decisions and experiences far beyond mobility itself.

In the analysis of the interviews, the issue of "sense of place" (Relph 1997) within mobility emerged, which is linked to the perception of the freedom of circulation within the enlarged EU. The participants expressed their opinion regarding the places they inhabit while moving. Their perceptions change as a consequence of their mobility and the condition of European citizens within the context of the economic crisis. Given the precariousness of their labour mobility towards Spain and the economic hardships entailed in moving between two places, in this study, we detect two ways of understanding the sense of place within mobility:

1) Persons who locate their "place" in the country of their birth, noting that they need to have a "site" to which they may return despite the difficulties in their country. Their narratives focus on the specificity of Romania, viewed in a contradictory manner as being both a place of opportunities and a place of no hopes, forcing them to leave and yet to always come back, thus illustrating the underlying problem of mobility: people leave for a better life, but still dream of being able to "make it" at home.

According to Feldman (1990), people who repeatedly change residence try to preserve the continuity of residential experiences by moving to places that resemble their former home places.

I live here, but I am over there, even though physically I know that I cannot live in my country. They allow me to move within Europe, all right, because I believe that Romania - just like Spain - is Europe (male, age 34, Madrid).

The interviewees emphasized the desperation and precariousness of the situation in which they live in Romania, and consider themselves to be a "generation of sacrifice" while pointing out the impossibility of accomplishing their professional goals. At the same time, they note the lack of employment stability in Spain that would create a sense of belonging.

2) Persons who report that they keep two places in mind: a place in their country of origin and a place in the host country, because these have similar characteristics and the two are now a part of each other. 
Well, I have two homes and the following occurs to me: when I return I think about this house and when I am here, it is on festivals and Sundays that I feel nostalgic and I think about the home over there. So, there you have it, I have two homes, I am from here and there, and there is no trouble, no suffering. Since there are two languages in my head, it is normal to have two homes, right? (female, age 43, Castellón).

For them, a place away from Romania, the discovery of Spain, and the mobility between two places came to represent opportunities for personal growth, freedom, knowledge, experience, and the possibility or ability of transcending one's "own" (home) place (Buttimer 1980). Here, respondents expressed a desire to "get out and obtain new work experiences," to "see my life from another perspective," to try out something new, to find new ways of thinking, and to learn. Place and the mobility to, from, and between them represented personal development. Mobility seemed to give them a sense of freedom and of being in control. It proved them able to transcend their home place, to decide for themselves where they wanted to go and where they wanted to stay. Some respondents claimed that they were "mobile European citizens" that did not care about places, and that it did not really matter where they lived.

I live here like I live over there; I am a citizen of Europe and what matters is not the place. What matters is having work somewhere (female, age 24, Madrid).

Both categories, however, link place to the notion of stability and security. They do this because they live with a lack of social or existential security in their movement and their perceptions. Life on the move, "for a short time", is an individual strategy which is born from the impossibility of becoming integrated into institutional structures and planning one's own future in one place, given the current economic and labour environment. Thus, we can speak of a kind of equilibrium in the interviewees' perception of place and mobility.

When speaking about the issue of the perceptions of mobile citizens within the EU, the interviewees point out that Romania's entry into the EU should have offered stability to people who engage in labour mobility in Europe. They note the lack of unity among Romanians in Spain and the bad image that their country has and which influence the EU and the Spanish government to impose restrictions on work.

We have no confidence because Romania has a very bad reputation in Europe. We will have to wait another 20 years for the results to be seen. We Romanians are sacrificed: condemned to wander because we cannot live in our own country. Besides, we are not united; we live in ignorance, utterly uninformed and careless (male, age 49, Madrid).

On one hand, they celebrate their freedom to circulate within the EU with only an identity document, while on the other they expressed their disagreement with Spanish regulations and said they suffer discrimination in the labour markets of Spain and the EU. For 75 per cent of the interviewees, the EU means returning to a world of which they will always be a part, even while they recognize that it is difficult for Romanians to find a place in Europe. They point out the fact that mobility within the EU has led them to 
lower categories of work; they work in the informal economy, without rights, and they will continue to do so until Romania displays "a new standard of living".

We are second-rate; we are used for Spain's interests. When they are not interested (in our work), the restrictions come and we lose our rights. I think it is unjust, but that is the way it is because everything is a matter of money, and now it is scarce. Europe? They treat us badly and exploit us. I believe that every human being has a place under the sun. If Europe rejects us because we are Romanian, it will convert us into indigent European citizens without rights (female, age 38, Madrid).

Furthermore, they feel that they are discriminated against because "if the measure had been also applied to the other immigrant communities, it would not have hurt as much", and "but it is only for us and this is shameful and humiliating". Interviewees are confident that the end of the crisis and the complete integration of their country into the EU will remedy this situation because "after working in Spain, paying into Social Security, and building up the country", they are left without rights; now, what they want most of all is to "build in Romania not only their homes but their lives as well".

\section{Conclusions: the making of a mobile citizen in between}

After making the analysis, within the space that emerged from the opening of the borders of the EU towards Eastern Europe, I venture to say that a new theoretical framework is needed to analyze the labour mobility of the 'new' citizens of Europe in the $21^{\text {st }}$ century (Gielis 2009; Recchi \& Favell 2009).

1) First, I consider labour mobility a new and fundamental aspect of social life in the $21^{\text {st }}$ century, following the turbulent process of Romanian migration at the end of the $20^{\text {th }}$ century. The boundaries between home and away, local and global, traditional and detraditionalized, and here and there have become increasingly blurred (Skrbis et al. 2004). In a world without borders, the logic of perpetual mobility entered into their scheme: the process of provisional return to the country of origin or, in other words, the life of a citizen involved in circulatory labour mobility between two countries, two worlds and two languages.

2) Second, through the use of terms such as experience and understanding of mobility, we can attempt to capture the idiosyncrasy of a person who moves within the culture created by a mobile community, the experiences and the understanding of mobility, as they are perceived by the persons involved in this continuous and circuitous process. By delving into the lives of people on the move, it is possible to understand the nature of labour mobility on a global scale. Also, discussion about place and mobility may even explain circulation and return within the framework of current mechanisms of mobility within the space encompassed by EU border policy.

3) Finally, in this article, I used the border argument to increase our knowledge of mobile citizens that live "in between" in an expanded Europe. When migrants experience being "in between", or in other words, when they experience the difference between here (the new country of residence) and there (the former country of residence), this can be understood as a border experience. In my view, mobile citizens live not only with 
state borders but also with various other kinds of borders, such as mental and symbolic ones. These mental processes create a kind of present-absent border. Thus, the concept of border is not an enemy of mobile citizens, but rather has become a "friend" who enriches our understanding of the complexities and ambivalences of movers' in-between lives.

Therefore, in summing up the analysis of comments by Romanians about their mobility between Spain and their country of origin, we conclude that it comes from understanding the dynamics of Romanian migration in Spain and the EU. In a world without borders, the logic of perpetual mobility includes the process of a provisional return to the country of origin within its reasoning: in other words, the existence of a citizen on the move between two countries, two worlds, and two languages (Marcu 2010).

This is how a European mobile citizen, who seeks work in any country on the Community territory with help from networks established over time, is formed. In this context, despite the crisis and labour precarity, Spain is at the heart of European mobility because of the intensity of provisional settlement on the part of Romanians within its confines.

\section{References}

- $\quad$ Albrow, M. (1996) The global age: State and society beyond modernity, Polity: Cambridge.

- $\quad$ Buttimer, A. (1980) 'Home, Reach, and the Sense of Place'. In Buttimer A and Seamon D (eds.) The Human Experience of Space and Place, pp.166-187. Croom Helm: London.

- Calhoun, C. (1991) 'Indirect relationships and imagined communities: Large-scale social integration and the transformation of everyday life'. In Bourdieu P and Coleman J (eds.) Social theory for a changing society, pp. 95-121 Boulder, CO: Westview.

- Cassarino, J. P. (2004) 'Theorizing Return Migration. The Conceptual Approach to Return Migration Revised', International Journal of Multicultural Societies, 6: 253-279.

- Diminescu, D. (2009) 'Exercitiul dificil al liberei circulatii: o introducere in istoria migratiei recente a românilor'. In Anghel R and Horvath I (eds.) Sociologia Migratiei. Teorii si studii de caz românesti, pp. 45-62 Polirom : lasi.

- Diminescu, D. (2003) Introduction. In Diminescu D (ed) Visibles Mais Peu Nombreux. Les Circulations Migratoires Roumaines, pp. 1-23 Editions de la Maison des sciences de l'homme : Paris.

- Diminescu, D. and Lazaroiu S. (2002) Circulatory Migration of Labour Forces from Romania. IOM.

- Elrick, T. and Ciobanu, O. (2009) 'Migration networks and policy impacts: Insights from Romanian-Spanish migrations', Global Networks, 9 (1): 100-116.

- Ezzy, D. (2002) Qualitative Analysis: Practice and Innovation, Allen \& Unwin: New South Wales. 
- Faist, T. (2000) The Volume and Dynamics of International Migration, Oxford University Press: New York

- Faist, T. (2007) 'Transnationale Migration ale relative immobilität in einer globalisierten Welt ', Berliner Journal für Soziologie, 17/3: 415-437.

- Favell, A. (2008) 'The new Face of East-West Migration in Europe', Journal of Ethnic and Migration Studies, 34/5: 701-716.

- $\quad$ Feldman, R. (1990) 'Settlement-identity: Psychological bonds with home places in a mobile society', Environment \& Behavior, 22:183-229.

- Gielis, R. (2009) 'Borders make the difference: migrant transnationalism as a border experience', Tijdschrift voor Economische en Sociale Geografie, 100: 598-609.

- Glick Schiller, N. Basch, L. and Szanton Blanc, C. (1995) 'From immigrant to transmigrant: theorizing transnational migration', Anthropological Quarterly, 68/1: 4863.

- Goldring, L. (1996) 'Blurring borders: constructing transnational community in the process of Mexico-US migration', Research in Community Sociology, 6: 69-104.

- Gribch, C. (2007) Qualitative data analysis: An introduction. Sage: London.

- Hannam, K. Sheller, M. and Urry, J. (2006) 'Editorial: Mobilities, Immobilities and Moorings', Mobilities, 1/1: 1-22.

- Hannerz, U. (1996) Transnational connections: Culture, people, places. Routledge: London.

- King, R, and Christou, A. (2011) 'Of Counter-Diaspora and Reverse Transnationalism: Return Mobilities to and from the Ancestral Homeland ', Mobilities, 6/4: 451-466.

- $\quad$ King, R. (1978) 'Return Migration: A Neglected Aspect of Population Geography', Area, 10/3: 175- 183.

- Long, L. D. and Oxfeld, E. (2004) Introduction: an ethnography of return. In: Long L.D and Oxfeld E. (eds.) Coming Home? Refugees, Migrants and Those Who Stayed Behind, pp. 1-15. University of Pennsylvania Press: Philadelphia.

- Marcu, S. 2010. Del Este al Oeste. Geopolítica fronteriza e inmigración de la Europa oriental a España. Salamanca: Servicio de Publicaciones, Universidad Salamanca.

- Meinhof, U. (2002) Living (with) Borders: Identity Discourses on East-West Border in Europe, Ashgate: Aldershot.

- Michalon, B. (2009) 'Cât de specifice sunt migratiile germanilor din România? Etnicitate, retele si circulatie migratorie'. In Anghel, R and Horvath, I (eds.) Sociologia migratiei. Teorii si studii de caz românesti, pp. 86-104. Polirom: lasi.

- Morokvasik-Müller, M. (1999) 'La mobilité transnationale comme ressource: le cas des migrants de l'Europe de l'Est', Cultures \& Conflits, 33/4 : 105-122.

- Newman, D. (2006) 'The Lines that Continue to Separate Us: Borders in our 'Borderless' World', Progress in Human Geography, 30:143-161.

- Portes, A. (2001) 'The debates and significance of immigrant transnationalism', Global Networks, 1/3:181-193.

- $\quad$ Recchi, E. and Favell, A. (2009) Pioneers and European Integration: citizenship and mobility in the European Union, Edward Elgar Publishing: London.

- $\quad$ Relph, E. (1997) 'Sense of Place'. In Hanson, S. (ed.) Ten Geographic Ideas that Changed the World. New Brunswick, Rutgers University Press: New Jersey. 
- $\quad$ Rotariu, T. and Mezei, E. (1999) 'Aspects of the Recent Internal Migration in Romania', Sociologie Româneasca, 3: 5-34.

- Sandu, D. (2010) Lumile sociale ale migratiei românesti in strainatate, Polirom; Bucuresti.

- Sandu, D. (2009) Comunidades Rumanas en España. Fundatia Soros: Bucuresti

- Sandu, D. (2006) Living abroad on a temporary basis. The Romanians and the economic migration: 1990-2006. Fundatia Soros: Bucuresti.

- $\quad$ Serban, M. and Voicu, B. (2010) 'Romanian migrants to Spain: in- or outside the migrant networks - a matter of time? ' Revue d'études comparatives Est-Ouest, 41/4:97125.

- Skrbis, Z, Kendall, G. and Woodward, I. (2004) 'Locating Cosmopolitanism: Between Humanist Ideal and Grounded Social Category', Theory, Culture \& Society, 21/6: 115-136.

- Van Houtum, H. (2005) 'The Geopolitics of Borders and Boundaries', Geopolitics, 10: $672-679$.

- Vertovec, S. (1999) 'Conceiving and Researching Transnationalism', Ethnic and Racial Studies, 22/2: 447-477.

- Vertovec, S. (2004) 'Migrant Transnationalism and Modes of Transformation', International Migration Review, 38:970-1001.

- Viruela, R. (2011) 'The Romanian Migrants in Spain. An Exceptional Migratory Flow'. International Review of Social Research 1/1: 31:59.

- Wallace, C. and Stola, D. (2001) Patterns of Migration in Central Europe, Palgrave: Houndmills. 


\section{Figures}

Figure 1. Employment situation of working age (15-64) Romanian nationals residing in Spain (\%)

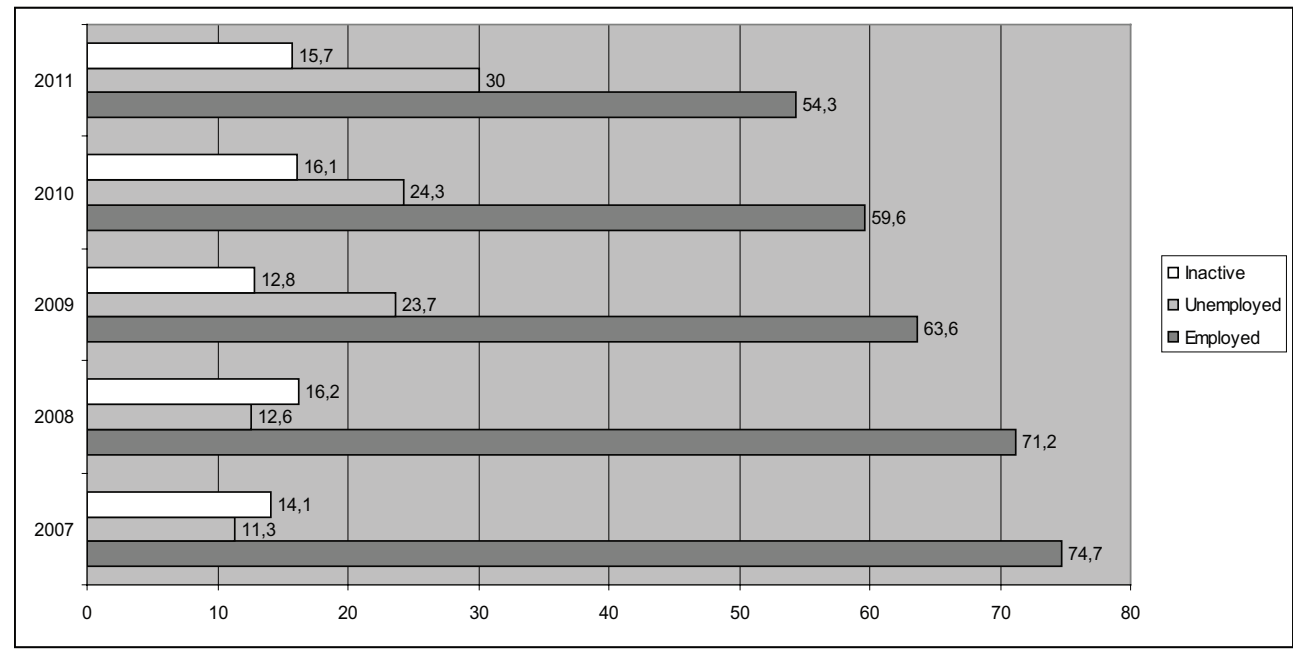

Source: Spanish Ministry of Labour and Immigration 2011

Figure 2. Dynamic migration of Romanians in Spain: Evolution of flows

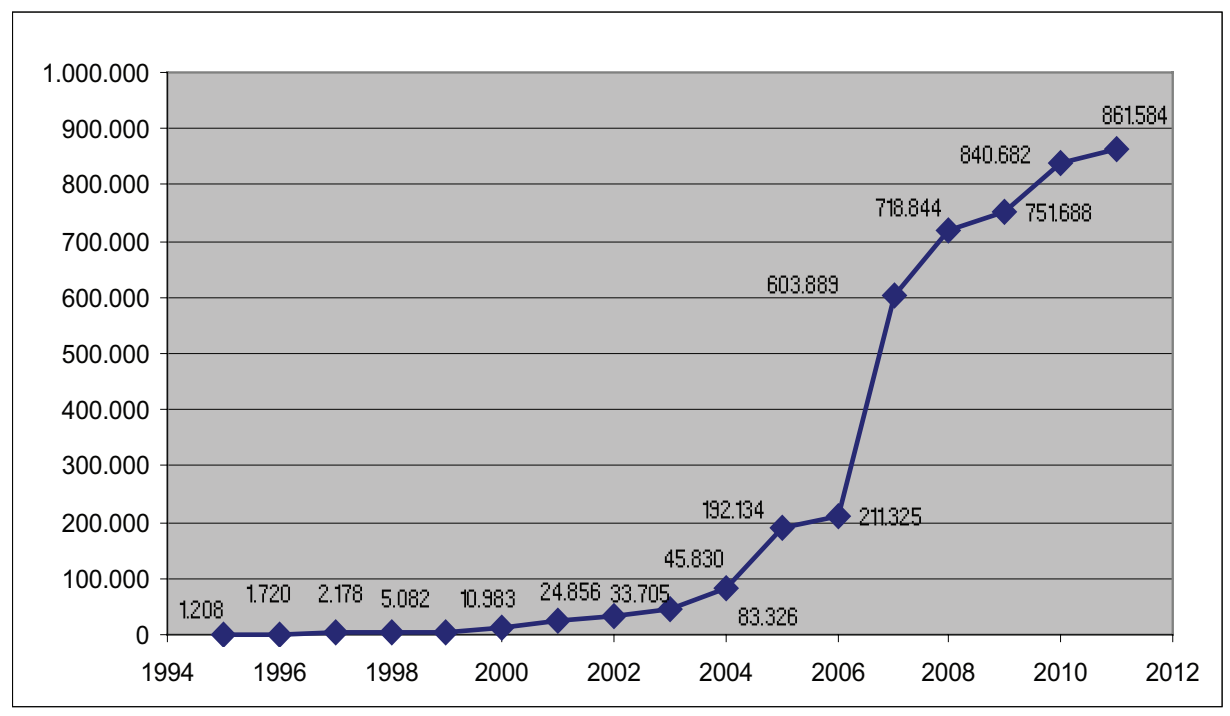

Source: Spanish Ministry of Labour and Immigration, 2011 


\section{Silvia Marcu}

Figure 3. Evolution of the unemployed and Spanish Social Security affiliates (20072011)

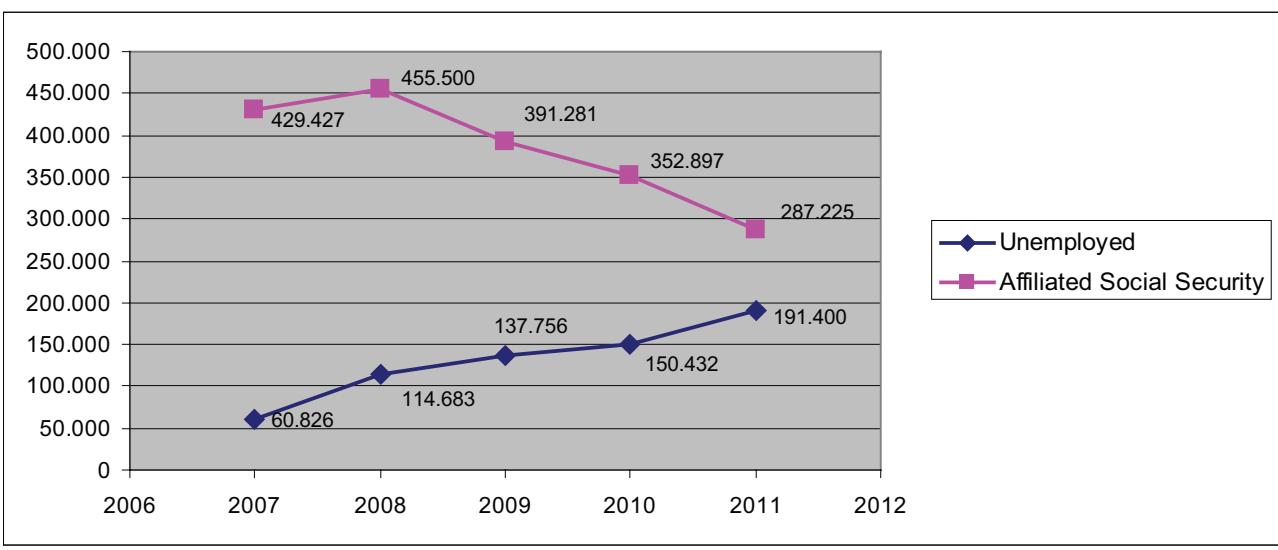

Source: Spanish National Institute of Statistics, 2011. Author's analysis. 